\title{
Long noncoding RNA and protein abundance in IncRNPs
}

\author{
MAN WU, ${ }^{1}$ LIANG-ZHONG YANG, ${ }^{1}$ and LING-LING CHEN ${ }^{1,2,3}$ \\ ${ }^{1}$ State Key Laboratory of Molecular Biology, Shanghai Key Laboratory of Molecular Andrology, CAS Center for Excellence \\ in Molecular Cell Science, Shanghai Institute of Biochemistry and Cell Biology, University of Chinese Academy of Sciences, \\ Chinese Academy of Sciences, Shanghai 200031, China \\ ${ }^{2}$ School of Life Science and Technology, ShanghaiTech University, Shanghai 201210, China \\ ${ }^{3}$ School of Life Science, Hangzhou Institute for Advanced Study, University of Chinese Academy of Sciences, Hangzhou 310024, China
}

Editor's Note:

Ling-Ling Chen was the recipient of the 2021 Mid-Career Research Award presented by the RNA Society.

\begin{abstract}
Although long noncoding RNAs (IncRNAs) are generally expressed at low levels, emerging evidence has revealed that many play important roles in gene regulation by a variety of mechanisms as they engage with proteins. Given that the abundance of proteins often greatly exceeds that of their interacting IncRNAs, quantification of the relative abundance, or even the exact stoichiometry in some cases, within IncRNA-protein complexes is helpful for understanding of the mechanism(s) of action of IncRNAs. We discuss methods used to examine IncRNA and protein expression at the single cell, subcellular, and suborganelle levels, the average and local IncRNA concentration in cells, as well as how IncRNAs can modulate the functions of their interacting proteins even at a low stoichiometric concentration.
\end{abstract}

Keywords: IncRNA; IncRNP; concentration; abundance; stoichiometry; single cell; subcellular; suborganelle

\section{INTRODUCTION}

The vast majority of the human transcriptome consists of non-protein coding RNAs (ncRNAs), among which those longer than $200 \mathrm{nt}$ are defined as long noncoding RNAs (IncRNAs) (Derrien et al. 2012). The latest annotation suggests that human IncRNAs exceed 170,000 (Zhao et al. 2021), although in a cell-/tissue-specific expression manner (Kim et al. 2015; Seifuddin et al. 2020). Currently annotated IncRNAs comprise species that are derived from different genomic origins and are processed by distinct mechanisms (for reviews, see St Laurent et al. 2015; Wu et al. 2017; Kopp and Mendell 2018). Over the past decade, well-documented studies focused on IncRNA modes of action have shown that these large and single-stranded molecules are often functionally engaged with distinct sets of proteins (Statello et al. 2021). They can act as guides, recruiters, scaffolds and decoys to modulate the structure and function of chromosome architecture and nuclear condensates, to regulate transcriptional and post-transcriptional processes, or to directly interfere with mRNA translation, post-translational modifications and signaling

Corresponding author: linglingchen@sibcb.ac.cn

Article is online at http://www.rnajournal.org/cgi/doi/10.1261/rna. 078971.121. Freely available online through the RNA Open Access option. pathways. Thus, IncRNAs can trigger significant cellular responses in many biological contexts.

Given their large size and flexible conformation, it remains a challenge to fully understand how IncRNAs exert their effects. In particular, the abundance of RNA binding proteins (RBPs) often greatly exceeds that of interacting IncRNAs, except in a few cases, such as the human telomerase reverse transcriptase ( $h T E R T)$ and the telomerase RNA ( $h T R$ ) that form an IncRNP at about a 1:1 ratio (Xi and Cech 2014; Ghanim et al. 2021). Quantitative comparison of IncRNA and protein levels shows that the copy number of the majority of proteins per cell varies from 10,000 to $80,000,000$ (Hein et al. 2015), remarkably exceeding that of IncRNAs, with expression of 0.3-1000 molecules per cell (Table 1). Further, most proteins associate with many other factors, not just IncRNAs to which they can bind. Thus, distinct mechanisms have been adapted by IncRNAs to overcome their low abundance compared to their interacting proteins for achieving measurable effects. Understanding the subcellular localization of IncRNAs and the local concentrations of both proteins and RNAs is

(C) 2021 Wu et al. This article, published in RNA, is available under a Creative Commons License (Attribution-NonCommercial 4.0 International), as described at http://creativecommons.org/licenses/by-nc/4.0/. 


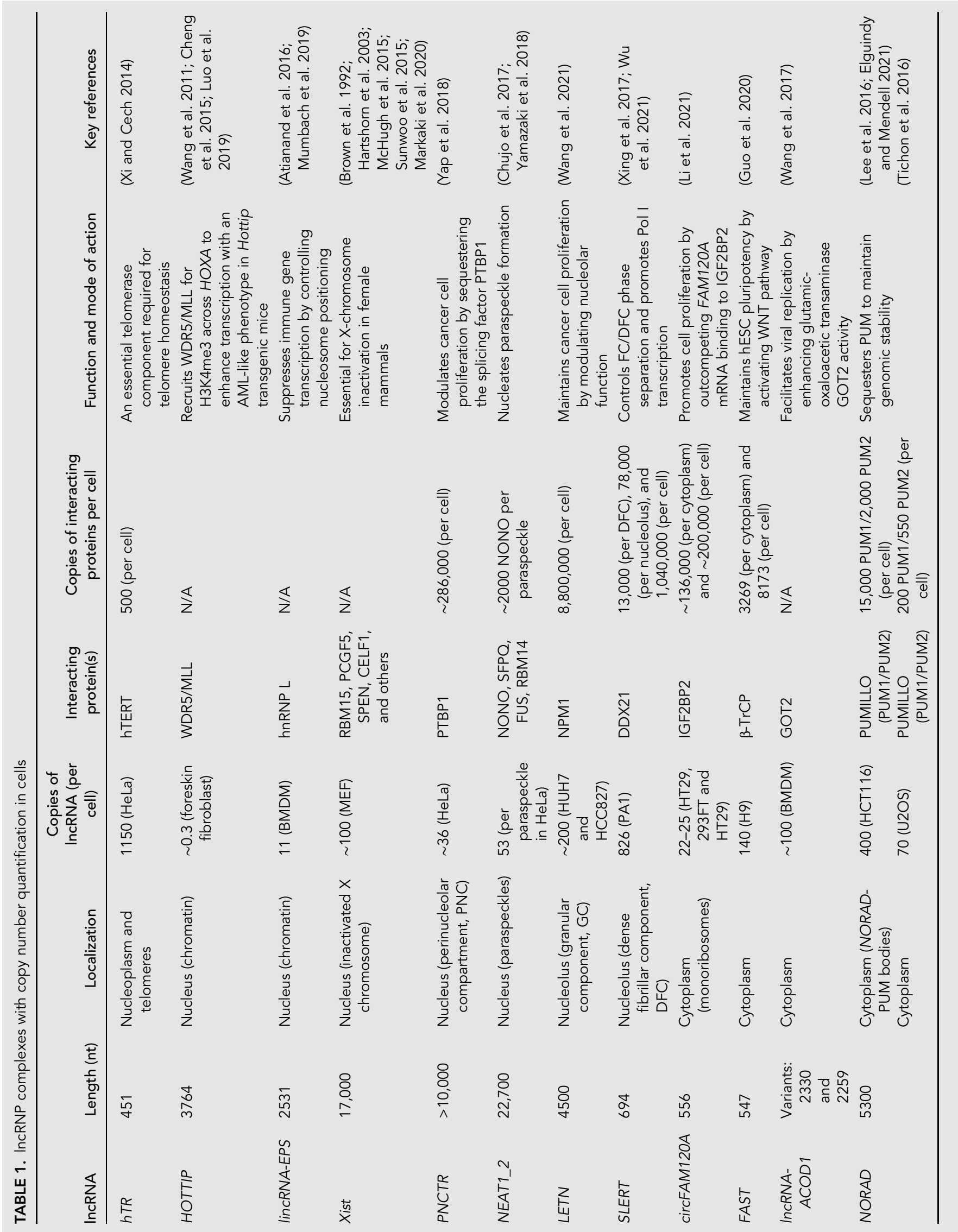


therefore more informative mechanistically than only knowing average cellular concentrations.

As one example, for cis-acting IncRNAs, an abundance of one to 10 molecules per cell is likely sufficient for functioning at a single locus or at several loci by directly basepairing with the genomic DNA or by recruiting chromatin modifiers to impact transcriptional outputs. This would explain how a number of low-abundance IncRNAs have been shown to exert pronounced biological effects (Table 1). For trans-acting IncRNAs, a higher abundance (10-1000) has been reported for their potential roles as recruiters, scaffolds, or decoys of proteins. Of note, such a higher abundance is still far below that of their interacting proteins; thus, the exact working model of a particular IncRNA depends not only on how many RBP binding motifs or structural modules exist within the IncRNA but also on its subcellular distribution (Table 1). In addition to relative abundance, it is worthwhile noting that the exact stoichiometry of IncRNA and protein within a functional IncRNP can provide clues into detailed IncRNA working mechanisms, as illustrated by well-studied IncRNPs, such as NORAD interacting with PUMILIO (PUM) (Elguindy and Mendell 2021), and SLERT interacting with DDX21 (Wu et al. 2021). In this review, we summarize methods used to quantify IncRNA and interacting RBPs at the cellular, subcellular and suborganelle levels. We also discuss how cells deal with the generally low IncRNA-protein concentration ratios through a variety of regulatory modes of action.

\section{STOICHIOMETRY OF CLASSICAL IncRNPs}

Several classical cellular ribonucleoprotein complexes (RNPs) have now been well studied such as the catalytic ribonucleoprotein complex RNase MRP involved in precursor ribosomal RNA (Lan et al. 2020), the RNase P complex that selectively cleaves transfer RNA-like substrates (Guerrier-Takada et al. 1983; Bartkiewicz et al. 1989; Evans et al. 2006) and the telomerase complex that acts in lengthening telomeres during DNA replication (Kim et al. 1994). For each of these functional RNPs a defined stoichiometry of RNAs and proteins is required for their assembly (Gray and Gopalan 2020). A useful example is the human telomerase that is minimally composed of a catalytic hTERT and an RNA component, hTR. hTR is a $451 \mathrm{nt}$ IncRNA acting as the template for telomere elongation by associating 1:1 with hTERT that is capable of de novo DNA synthesis (Schmidt and Cech 2015). Stoichiometric analyses by spike-in qRT-PCR and northern blotting (NB) experiments showed $\sim 1150$ hTR per HeLa cell, and by a two-step immunoprecipitation (IP)-western blotting (WB) method showed 500 hTERT per HeLa cell (Xi and Cech 2014). Interestingly, quantification of endogenous levels of telomerase revealed $\sim 240$ active telomerase monomers or $\sim 120$ dimers, a number comparable to that of telomeres in late $\mathrm{S}$ phase per HeLa cell (Cohen et al. 2007; Xi and Cech 2014). These analyses suggested that telomerase was not an abundant RNP and that unassembled nontelomerase hTR or hTERT existed in cells. Overexpression of either hTR or hTERT led to increased telomerase activity, supporting the notion of a quick assembly of the subpopulations of nontelomeric hTERT and $h T R$ into functional telomerases in cells (Xi and Cech 2014). Methodologically, the nonequivalence of copy number between telomerase and its components indicates that only measuring the total cellular copy number of a IncRNA of interest and its corresponding protein may be inadequate to indicate the relevant abundance of functional IncRNPs.

\section{METHODS TO DETECT THE ABUNDANCE OF IncRNAs AND THEIR ASSOCIATED RBPs}

Different from $h T R$ and hTERT in telomerase, most IncRNA-binding proteins also bind to many other RNAs in cells; thus, it is important to detect the relative abundance of IncRNAs and their associated RBPs within the particular IncRNPs for functional insights. Also, unlike telomerase, which can be quantified by telomerase activity, we lack biochemical assays to detect most IncRNP complexes. Methods to quantify IncRNA expression have therefore moved from classic biochemical quantification (Xi and Cech 2014; Lee et al. 2016; Xing et al. 2017) to combining subcellular fractionation and quantitative imaging (Guo et al. 2020; Li et al. 2021), and more recently, high resolution microscopy at the suborganelle level to dissect the relative abundance of IncRNA and protein in IncRNPs (Wu et al. 2016; Yao et al. 2019; Elguindy and Mendell 2021; Wu et al. 2021).

\section{BIOCHEMICAL QUANTIFICATION OF InCRNAs AND RBPs IN CELLS}

Biochemical quantification is the most well-established method to calculate the average IncRNA copy number per cell. To do so, one needs to construct an in vitro benchmark system, termed a "standard curve," which can be generated by using NB or qRT-PCR (Xi and Cech 2014; Xing et al. 2017; Li et al. 2021; Wu et al. 2021) analyses with a series of dilutions of purified in vitro transcribed (IVT) IncRNAs of interest (Fig. 1A). Then, the total RNA extracted from a defined number of cells (i.e., 1 million cells) is collected and subjected to NB followed by band quantification or by qRT-PCR to obtain the respective $C_{t}$ values. Based on the standard curve (Fig. 1A), the copy number of a particular IncRNA per cell can be determined by dividing the total number of cells used to extract the total RNA.

One must take two matters into consideration during this biochemical quantification protocol. First, for RNAs that are strongly encapsulated with proteins, chromatin, 
A

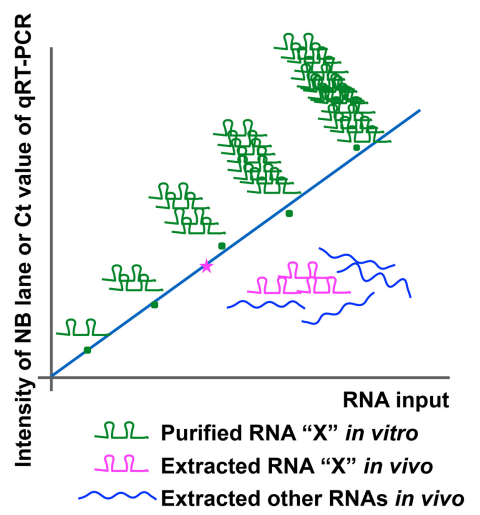

C

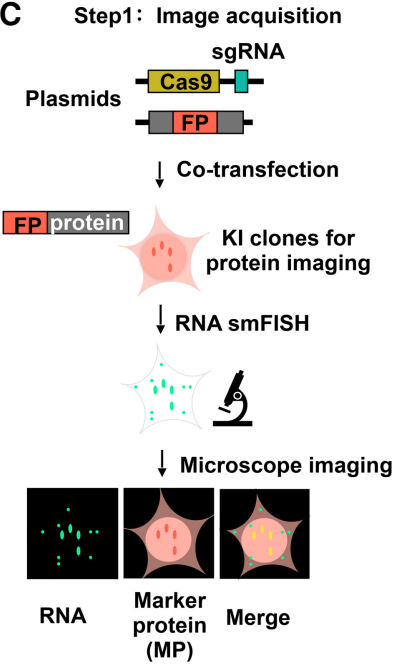

D
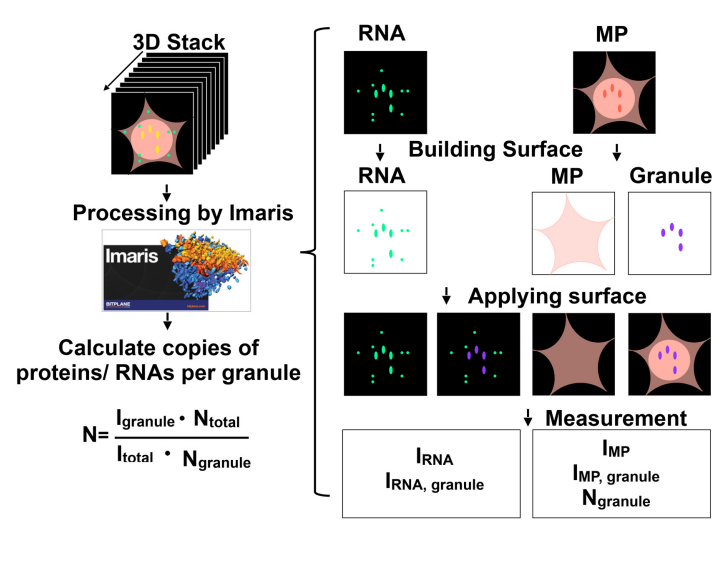

FIGURE 1. Quantification of cellular and subcellular IncRNA expression. (A) A workflow to illustrate the biochemical quantification of the copy number of a IncRNA per cell. The standard curve is generated by northern blotting or qRT-PCR of in vitro transcribed and purified RNA " $\mathrm{X}$ " at different concentrations. Total RNA is extracted from a certain number of cells by means of classical TRlzol or an improved heat/shearing TRlzol method. See text for detail. (B) A pipeline of isolating cytoplasmic, nuclear soluble, and insoluble fractions to quantify IncRNA at the subcellular level. See text for detail. $(C, D)$ Imaging quantification of IncRNP components at subcellular and suborganelle levels (Yao et al. 2019; Wu et al. 2021). (C) Image acquisition. Firstly, the gene locus of the marker protein in the region of interest (ROI) is tagged with fluorescence protein (FP) via CRISPR/Cas9-mediated knock-in (KI) to circle the subdomain. smFISH of the target IncRNA is performed to gain signals of the IncRNA of interest in the whole cell. (D) Imaging processing. 3D stacks of the protein and the IncRNA of interest are imported into Imaris. 3D rendering of the maker protein and the IncRNA was produced, respectively, with surface building function modules to obtain their integrated densities within corresponding surfaces. The percentage of the protein and the IncRNA in ROI is calculated by the formula shown in the panel, where $N$ is the copy number of proteins/RNAs per granule, Igranule is the intensity of proteins/RNAs in total granules, $I_{\text {total }}$ is the intensity of proteins/RNAs in the whole cell, $N_{\text {total }}$ is the copy number of proteins/RNAs per cell, and $N_{\text {granule }}$ is the number of granules per cell.

nuclear matrix or in dense condensates in cells, it is compulsory to utilize an improved RNA extraction method by shearing or heating to disrupt such dense complexes, thereby leading to enhanced extractability of RNA by TRIzol (Chujo et al. 2017; Wu et al. 2021). Second, we highly recommend the use of IVT RNA rather than plasmid
DNA as the template to generate the standard curve. Using IVT RNAs as the template for standard curves involves a cDNA synthesis step and thus takes the efficiency of the reverse transcription reaction into account. Furthermore, knowing a copy number of a particular RNA per cell, by combining the RNA-seq transcriptomic data, one can roughly get an idea of the copy number of additional RNAs by comparing their expression in samples with the same sequencing depth (Liu et al. 2019).

In principle, in these biochemical quantifications, specificities of NB probes and QRT-PCR primers are of importance to be considered to avoid potential bias in calculating concentrations (Li et al. 2021). For instance, using different qRT-PCR primer sets targeting $h T R$ gave noteworthy differences in $h T R$ levels, even as much as 10 -fold variation. To solve this concern, gradient dilutions of in vitro purified $h T R$ as spike-in were incorporated into the endogenous $h T R$ to obtain qRT-PCR signals for abundance (Xi and Cech 2014).

Similarly, the copy number of a protein of interest per cell can be calculated, by first generating the standard curve as a reference concentration with a series dilution of purified proteins by WB and then calculating the protein copy number from a defined number of cells (Li et al. 2021). Of note, the accuracy of antibodies for WB should be considered to avoid potential misdetection. On the other hand, though, mass spectrometry (MS)-based quantitative proteomics provides a sensitive way to analyze proteins on a global scale across cell and tissue type (Aebersold and Mann 2003; Schubert et al. 2017). Generally, there are two quantitative MS strategies, isotopic labeling (Gygi et al. 1999; Ong et al. 2002; Ross et al. 2004) and label-free approaches (Chelius and Bondarenko 2002; Ahrne et al. 2013). Among isotopic labeling methods, SILAC (stable isotope labeling with amino acids in cell cultures) (Ong et al. 2002; Wang et al. 2018a) is the most popular strategy in which specific amino acids with a nonradioactive, isotopically labeled form are 
incorporated into all proteins in given samples. For labelfree absolute quantification, all proteins are digested into peptides and subjected to liquid chromatography to measure the summarized ion counts; then these counts are converted into signal values compared to the total amount of proteins injected into the mass spectrometer, or correlated to a set of spike-in reference peptides with known concentrations (Chelius and Bondarenko 2002; Ludwig et al. 2012). Although large scale quantification is allowed in these measurements, a huge number of cells is required to gain confidence in quantitative MS, because the readout is limited as a proxy for protein levels. Consequently, single-cell proteomics, termed scMS, has major limitations on throughput and proteomic depth (Budnik et al. 2018; Zhu et al. 2018). Nevertheless, in principle, the copy number of a protein of interest can be extracted for particular types of cells that have been analyzed by quantitative MS (Castello et al. 2012, 2016). This can then be used to determine the levels of RBPs containing intrinsically disordered regions (IDR) in RNA interactomes that have emerging roles in phase separation (Das et al. 2014; Zhang et al. 2015; Maharana et al. 2018; Zhou et al. 2018; Guillen-Boixet et al. 2020).

\section{BIOCHEMICAL QUANTIFICATION OF IncRNAs AND RBPs AT THE SUBCELLULAR LEVEL}

LncRNAs often possess subcellular preferences for function instead of being evenly distributed throughout the cell (Cabili et al. 2015; Wu et al. 2016; Sun et al. 2018). More than the copy number of a IncRNA per cell, its specialized localization indeed more profoundly impacts the function of its interacting proteins. One simple way used to determine subcellular localization involves separating cytoplasmic and nuclear RNAs followed by NB and qRT-PCR quantification (Fig. 1B). In brief, cells are treated with nonionic detergent, such as Igepal, to solubilize membrane lipids and release cytoplasmic contents. After centrifugation at low speed (i.e., $1000 \mathrm{~g}$ ), the soluble and cytoplasmic RNAs in the supernatant are extracted by TRIzol or other RNA extraction reagents (Chen et al. 2008; Lo Piccolo et al. 2015; DeCaprio and Kohl 2020). The pelleted nuclear fractions are further incubated with prolonged nonionic detergent or gentle ionic detergent, such as deoxycholate, to destroy the nuclear membrane and release nuclear soluble and insoluble fractions. The latter insoluble fractions mainly consist of chromatin-associated RNAs (Ramsby and Makowski 2011) and nuclear condensate-enriched RNAs (Chujo et al. 2017). In theory, the nuclear insoluble fraction is resistant to high salt, nonionic detergent and nuclease treatment; thus, special attention should be paid to isolate IncRNAs from the insoluble fraction using appropriate buffers (i.e., by including high salt, $2 \mathrm{M} \mathrm{NaCl}$ ) (Takata et al. 2009).
In the cytoplasm, some IncRNAs are specifically localized to certain organelles for function. For example, the IncRNA SAMMON is mitochondrial localized and plays a role in promoting melanoma growth and survival via binding mitochondrial p32 protein (Leucci et al. 2016). Some IncRNAs are enriched in ribosomal fractions and affect mRNA translation (Essers et al. 2015; Hansji et al. 2016). For instance, ZFAS1 binds to the small 40S ribosomal subunit and regulates ribosome production and assembly (Hansji et al. 2016). A recent study showed that circFAM120A bound the translational inhibitor IGF2BF2 to prevent this protein from engaging with FAM120A mRNA on monoribosomes, resulting in enhanced FAM120A mRNA translation (Li et al. 2021). It should be noted that FAM120A mRNA is expressed at 250-600 copies per cell, while circFAM120A is expressed at only 22 copies per cell. Interestingly, to be competitively competent for IGF2BF2 binding, the majority of circFAM120A, but just a small fraction $(<10 \%)$ of FAM120A mRNA, is specifically present on monoribosomes, resulting in a 3:1 to 5:1 of FAM120A mRNA and circFAM120A stoichiometry on the monoribosomes, as shown by polyribosome profiling assays that segregate single ribosomes and polyribosomes via sucrose gradients (Li et al. 2021). Such specific localization of circFAM120A provides a sufficient level to trap IGF2BP2 on monoribosomes, thereby facilitating FAM120A mRNA translation and ultimately cell proliferation (Li et al. 2021).

Inside the nucleus, isolating soluble and insoluble nuclear fractions can roughly indicate a subnuclear localization of IncRNAs, but it remains a challenge to delineate their precise subnuclear localization patterns using biochemical assays. Different types of membrane-less nuclear bodies are difficult to isolate biochemically. The largest nuclear structures, nucleoli (1-5 $\mu \mathrm{m}$ [Lafontaine et al. 2021]), are more amenable to be isolated from a nuclear fraction while other smaller nuclear bodies are far more difficult to purify using sucrose cushions. Isolation of nucleoli could be achieved by treating sonicated nuclear fractions with various concentrations of sucrose and magnesium chloride (Andersen et al. 2005), which allowed investigators to uncover the role of Alu-containing RNAs in the maintenance of nucleolar structure and function (Caudron-Herger et al. 2015). Paraspeckles (0.2-0.5 $\mu \mathrm{m}$ [Sasaki and Hirose 2009; Mao et al. 2011b]) are difficult to isolate biochemically and were discovered by immunofluorescence (IF) imaging validation of proteomic results of the sucrose densityisolated nucleolar components including PSP1 and NONO (Fox et al. 2002). IF with anti-PSP1 and antiNONO revealed that they did not localize to nucleoli but rather to previously undefined regions that are localized adjacent to nuclear speckles (Fox et al. 2002, 2005).

Beyond the above-mentioned traditional biochemical analyses, recently developed proximity labeling-based methods including BiolD (biotin identification) (ChoiRhee et al. 2004; Roux et al. 2012), APEX (engineered 
ascorbate peroxidase) (Martell et al. 2012; Hung et al. 2016), HRP (horseradish peroxidase) (Hopkins et al. 2000; Li et al. 2014), and PUP-IT (pupylation-based interaction tagging) (Liu et al. 2018), coupled with quantitative MS offer a high-throughput means for systematic analysis of spatially restricted proteomes (Bosch et al. 2021). In addition, RAP-MS (RNA antisense purification coupled with mass spectrometry) revealed Xist interacting proteins (McHugh et al. 2015), IP-MS identified thousands of proteins across almost all protein classes in HeLa cells (Hein et al. 2015) and RNA CHART (capture hybridization analysis of RNA targets) -seq using antisense oligonucleotides for NEAT1_2 revealed novel RNA components of paraspeckles (West et al. 2016) as well as the crosstalk between paraspeckles and mitochondria (Wang et al. 2018b). Moreover, DNA CHART-seq and CHART-MS of NEAT1 and MALAT1 have also been used to show the shared DNA and protein components between paraspeckles and nuclear speckles (West et al. 2014).

\section{IMAGING AND SUPER RESOLUTION IMAGING QUANTIFICATION OF InCRNPs AT THE SUBCELLULAR AND SUBORGANELLE LEVEL}

Compared to biochemical separation that is performed using bulk cells, imaging and super resolution imaging provide an in situ measurement of cellular components. Based on the biochemical quantification of IncRNA copy number per cell (Fig. 1A,B), the exact molecule number in designated localized regions can be examined by calculating fluorescent intensities of the regions of interest (ROI) and whole-cell regions through single molecule RNA FISH (smFISH) experiments of the target IncRNAs (Fig. 1C,D; Wu et al. 2016; Yao et al. 2019; Wu et al. 2021). Of note, $\mathrm{ROI}$ is represented by the known marker protein in the targeted subdomain (Fig. 1C,D). It is worthwhile mentioning that quantitative imaging demands high-resolution and high-quality images, devoid of unwanted contamination by background signal intensity.

The subregion quantification of a particular protein is similar to that of IncRNA by circling the interest region through protein IF imaging (Wu et al. 2016; Guo et al. 2020; Wu et al. 2021). Since the expression level of RNA and protein per cell is based on biochemical quantification from the standard curve generated from bulk cells (Fig. 1A, $B)$, the averaged quantification per cell does not account for cell-to-cell variability, and accordingly, the calculated copy number at a particular region can vary.

A more precise way for quantification of proteins in living cells is to fuse proteins of interest to a fluorescent protein such as monomeric enhanced green fluorescent protein (mEGFP) using CRISPR/Cas9 technology. This can be used to indicate both protein expression and localization. By generating a fluorescence intensity standard curve of purified mEGFP in vitro at different concentrations, the ex- act copy of protein in the whole cell and the specific subcellular region can be retrieved (Fig. 1C; Yao et al. 2019). However, one potential disadvantage of this method is that the fused mEGFP domain ( $27 \mathrm{kDa}$ ) may change the localization, stability or function of the protein of interest.

Recently developed super-resolution microscopy has enabled the observation and quantification of subcellular structures at the nanometer level (West et al. 2016; Wu et al. 2016, 2021; Xing et al. 2017; Colognori et al. 2019; Elguindy and Mendell 2021). By consolidating super-resolution imaging and specific cellular organelles of interest, the meaningful local concentration of RNA and protein in one IncRNP could be accurately calculated. For instance, structural illumination microscopy (SIM) allied with CHART RNA-seq using antisense oligonucleotides that target different NEAT1_2 regions revealed protein and RNA components arranged as core-shell structures in paraspeckles (West et al. 2016; Wang et al. 2018b). SIM, together with iCLIP RNA-seq, revealed the distinct binding preferences of IncRNA and RBPs in terms of sno-IncRNAs, SPA IncRNAs and splicing factors RBFOX2, hnRNP $M$ and TDP43 in a particular nuclear region that is absent from patients with Prader-Willi syndrome (PWS) (Wu et al. 2016).

\section{THE SUBCELLULAR LOCALIZATION AND ABUNDANCE OF IncRNAs PROVIDE CLUES ABOUT MODES OF ACTION}

Knowing the subcellular localization gives clues about whether a IncRNA acts in cis or in trans; combining its intrinsic sequence, conformational features and the IncRNA local concentration can further illustrate how a IncRNA exerts transcriptional or post-transcriptional effects by interacting with proteins that are expressed at different levels in cells (Fig. 2).

\section{LOW ABUNDANCE CHROMATIN-ASSOCIATED IncRNAs CAN BE INVOLVED IN THE IN CIS AND IN TRANS REGULATION OF TRANSCRIPTIONAL OUTPUTS}

Nuclear soluble and insoluble fractionation followed by qRT-PCR or RNA-seq analyses could first give clues about chromatin-associated IncRNAs (Fig. 1B) and their copy number per cell can be retrieved by biochemical quantification (Fig. 1A). Chromatin-associated IncRNAs are found to be expressed at low copy number, at a range of $0.3-100$ copies per cell (Table 1). Their modes of action can be classified into two groups: base-pairing with DNA through complementarity to form RNA:DNA hybrids (R-loops) or RNA:DNA triplexes and recruiting or sequestering chromatin-associated RBPs at one locus or several loci (Fig. 2A). It is worthwhile noting that these modes are not mutually exclusive, because base-pairing with DNA very often recruits specific proteins for functions. 
A Examples of working modes of chromatin-associated IncRNAs

a) Base pairing to DNA; act in cis or in trans

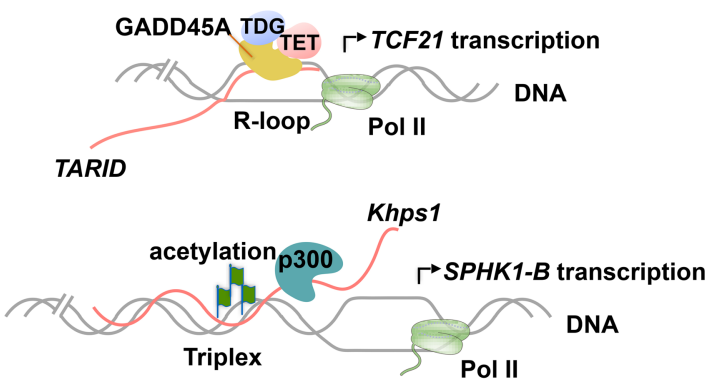

B Examples of working modes of trans-acting IncRNAs a) One IncRNA, multiple motifs or modules for one protein

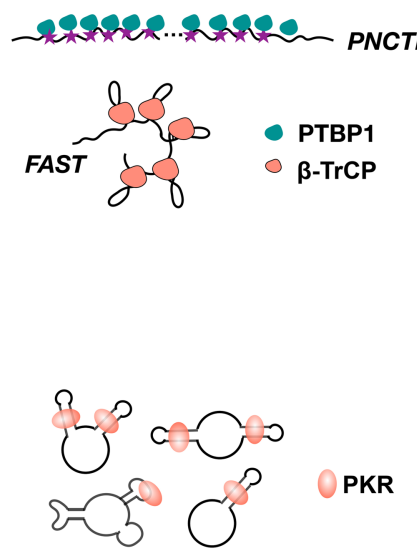

d) Multiple IncRNAs, multiple motifs, one protein b) Chromatin - association; act in cis or in trans

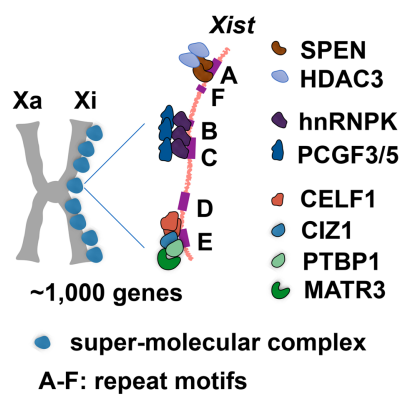

b) One IncRNA, multiple motifs, multiple proteins Paraspeckle NEAT1_2

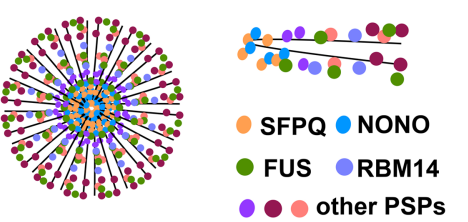

trans-acting modes

FIGURE 2. The subcellular localization and relative abundance of IncRNA determine its mode of action. (A) Examples of working modes of chromatin-associated IncRNAs. (a) Base-pairing with the complementary genomic DNA directs IncRNA localization and mode of action. (Top) IncRNA TARID (TCF21 antisense RNA inducing demethylation) forms an R-loop in the TCF21 (transcription factor 21, a tumor suppressor gene) CpG island promoter to recruit a proposed R-loop reader, GADD45A (growth arrest and DNA-damage-inducible, alpha), and cooperates with TET1 (10-11 translocation 1) and TDG (thymine-DNA glycosylase) to drive demethylation of the TCF21 promoter, resulting in TCF21 transcription activation (Arab et al. 2014, 2019). (Bottom) The IncRNA Khps1 (antisense orientation to SPHK1) forms RNA-DNA-DNA triplexes upstream of the transcription start site of proto-oncogene SPHK1-B (Sphingosine kinase 1, isoform B) with a purine-rich sequence. Khps 1 prompts an open chromatin structure by recruiting the histone acetyltransferase p300/CBP to the SPHK1 promoter to facilitate SPHK1-B transcription (Postepska-lgielska et al. 2015). (b) Chromatin-associated IncRNA Xist (X inactive specific transcript) serves as a recruiter paradigm along the female inactive $X$ chromosome (Xi), which contains 1000 genes (Tukiainen et al. 2017). Xist recruits different chromatin-modifying factors to form super-molecular complex (SMC) to silence adjacent genes on Xi (Brockdorff 2018). (B) Examples of working models of trans-acting IncRNAs. (a) One IncRNA possesses multiple binding motifs (top) (Yap et al. 2018) or forms multiple structural modules (bottom) (Guo et al. 2020) to decoy RBP function. (b) Locally enriched IncRNA interacts with multiple RBPs to form nuclear condensates. NEAT1_2 (nuclear paraspeckle assembly transcript 1, the long isoform) is the scaffold RNA of paraspeckles. It folds in half to keep the core region in the center and $5^{\prime} / 3^{\prime}$ termini in the shell within paraspeckles. The radially arranged NEAT1_2 provides an interacting network for paraspeckle proteins (West et al. 2016), among which SFPQ (splicing factor proline and glutamine rich) and NONO (non-POU domain containing octamer binding protein) play critical roles in initiating paraspeckle assembly (Yamazaki et al. 2018). (c) Multiple IncRNAs are enriched as a group to interact with RBPs. Five sno-IncRNAs (small nucleolar RNA-ended IncRNA) and two SPAs (5' small nucleolar RNA capped and 3' polyadenylated) are transcribed from the Ch15q11-13, and are absent in patients with PWS (PraderWilli syndrome). These IncRNAs interact with multiple RBPs to form microscopically visible foci that sequester RBPs to affect pre-mRNA alternative splicing (Wu et al. 2016). (d) Many circRNAs possess 16- to 26-bp duplexes and function as a group to inhibit PKR activation (Liu et al. 2019).

In the first scenario, a few copies per cell of IncRNAs that are associated with chromatin are likely adequate for their proposed modes of action. Formation of complex structures at specific genomic regions may in turn recruit additional chromatin modifiers and transcriptional factors to achieve a measurable gene expression change ( $\mathrm{Li}$ et al.
2016; Arab et al. 2019; Feretzaki et al. 2020). This can be exemplified by the IncRNA TARID (TCF21 antisense RNA inducing demethylation) that forms an R-loop at the TCF21 promoter in cis to trigger the sequential process of GADD45A recruitment, TET1 association, DNA demethylation and TCF21 transcription activation (Fig. 2A; 
Arab et al. 2014, 2019). In terms of the formation of triplex structures, Khps1 (antisense transcript of SPHK1) is tethered to the SPHK1-B promoter in cis via DNA-RNA triplexes and recruits p300/CBP to acetylate histones, promoting an active chromatin conformation to enhance SPHK1-B transcription (Fig. 2A; Postepska-lgielska et al. 2015).

In the second scenario, IncRNAs are located in the proximity of chromatin to scaffold or recruit protein binding (Fig. 2A). P53 induced intergenic noncoding RNA p21 (lincRNA-p21), is expressed at 20-80 copies per cell (Yang et al. 2014), interacts with hnRNP K and prevents reprogramming by maintaining the heterochromatic state of pluripotency gene promoters (Bao et al. 2015). Chromatin modifier complex deposition mediated by IncRNAs can also extend over a long range. The most prominent example is the IncRNA Xist, which is 17,000 nt in mouse and is transcribed exclusively from the inactive $X$ chromosome with $\sim 100$ copies per cell (Brown et al. 1992; Hartshorn et al. 2003; McHugh et al. 2015; Sunwoo et al. 2015; Markaki et al. 2020). Xist spreads directly from its transcription locus to distal sites across the $X$ chromosome (Lee and Bartolomei 2013; Markaki et al. 2020) in differentiated female cells to silence an $X$ chromosome by recruiting SPEN and a range of other proteins sequentially to form a transcriptionally silent nuclear compartment (Fig. 2A; Chu et al. 2015; Dossin et al. 2020; Markaki et al. 2020).

\section{LOCALIZED ENRICHED InCRNAs CAN CONTAIN MULTIPLE BINDING MOTIFS TO ACHIEVE HIGH EFFICIENCY AS DECOYS OR SCAFFOLDS FOR PROTEINS}

LncRNAs acting in trans as decoys or scaffolds in principle require higher abundance. However, even IncRNAs expressed at copy numbers ranging from dozens to hundreds of copies per cell are still outnumbered by their interacting proteins (Table 1). To overcome this issue, IncRNAs often harbor many binding motifs (Yap et al. 2018) or form multiple binding modules (Guo et al. 2020) to interact with proteins. Further, their localized accumulation offers a sufficiently high concentration to achieve measurable effects on interacting proteins, especially in that cellular neighborhood.

PNCTR is a $>10,000 \mathrm{nt}$ transcript produced by RNA polymerase I (Pol I). It is expressed only at $\sim 36$ copies per cell, is exclusively localized to the perinucleolar region (PNC) and is capable of recruiting a substantial amount of PTBP1 (Yap et al. 2018). PTBP1 is an apoptosis activator and prefers to bind YUCUYY and YYUCUY motifs (Fig. 2B), which are highly abundant in PNCTR sequence (2178 and 565, respectively). These motifs serve as PTBP1 concentration "sensors" and enable PNCTR to sequester 7\%-27\% cellular PTBP1 in theory, which indeed was confirmed as $11 \%-31 \%$ by quantifying IF-smFISH experiments. PNCTR thus provides ample binding sites for
PTBP1 to antagonize PTBP1 splicing regulation in a prosurvival function for cells (Fig. 2B; Yap et al. 2018). In another example, FAST is a $547 \mathrm{nt}$, cytoplasmic transcript that is expressed at 140 copies per human embryonic stem cell (hESC). It forms five independent stem-loops that allow binding of $\sim 700$ molecules of $\beta-\operatorname{TrCP}$ (an E3 ubiquitin ligase that targets phosphorylated $\beta$-catenin in the WNT destruction complex) (Fig. 2B), accounting for $>20 \%$ of the total \%3269 copies of $\beta$-TrCP in the cytoplasm (Guo et al. 2020). This has enabled a suppressed $\beta$-catenin degradation and activated WNT signaling that contributes to the maintenance of hESC pluripotency (Guo et al. 2020).

Except for being targeted by the same proteins, some IncRNAs can interact with a variety of proteins, exemplified by one of the most well-studied IncRNAs, NEAT1_2 (Fig. 2B). NEAT1_2 is a 22,700 nt transcript, expressed at 1000 copies per HeLa cell (Chujo et al. 2017) and serves as the key scaffold IncRNA of paraspeckles (Sasaki et al. 2009; West et al. 2016), a type of compact and membrane-less nuclear body exhibiting liquid-like properties (Yamazaki et al. 2018). In HeLa cells, each paraspeckle contains 50 NEAT1_2 molecules (Chujo et al. 2017), providing many binding sites for paraspeckle proteins (PSPs) via distinct subdomains (Hennig et al. 2015; Yamazaki et al. 2018). In the core-shell spheroidal structure of a paraspeckle, the $5^{\prime}$ and $3^{\prime}$ termini of NEAT1_2 display a shell localized pattern and the middle domain of NEAT1_2 contains several functional subdomains. The middle region of NEAT1_2 binds to NONO, SFPQ, and FUS, which is sufficient for paraspeckle assembly (West et al. 2016; Yamazaki et al. 2018). Among the over 40 identified paraspeckle proteins, NONO and SFPO have strong affinity with NEAT1_2 subdomain 12-13k, lower but substantial affinity with the adjacent 9.8-12k and 15.4-16.6k, to initiate paraspeckle assembly (Yamazaki et al. 2018). In addition, FUS provides an interaction network through its PLD (prion-like domain), leading to paraspeckle assembly via phase separation (Fox et al. 2018). This was also illustrated by RNA pull-down assays combining SILAC-MS analysis where quadruplex-forming G-rich sequences in NEAT1_2 were important for NONO, SFPQ, PSPC1 binding (Simko et al. 2020).

\section{DIFFERENT IncRNAs CAN ACT AS A GROUP TO ENSURE MEASURABLE EFFECTS ON PROTEIN INTERACTIONS}

In addition to the single type of IncRNA that acts as a decoy or scaffold, multiple different IncRNAs may localize proximately and act as a group by containing the same binding motifs for proteins; alternatively, different IncRNAs can form similar structural modules that allow the same protein to bind these RNAs to achieve a measurable effect. 
Five sno-IncRNAs and two SPA IncRNAs are paternally transcribed from Ch15q11-13, a region that is not transcribed in patients with PWS due to parental chromosome deletion, uni-chromosome disormy or epigenetic defects (Yin et al. 2012; Zhang et al. 2014; Wu et al. 2016). While PWS region sno-IncRNAs range from 1100 nt to $2900 \mathrm{nt}$ in size, SPA IncRNAs are larger transcripts, $34,000 \mathrm{nt}$ for SPA1 and 16,000 nt for SPA2. These snoRNA-biogenesis-facilitated IncRNAs are processed from the same polycistronic transcript driven by a strong paternal Pol II promoter (Wu et al. 2016), ultimately yielding relatively abundant SPAs and sno-IncRNAs (approximately one-third of the level of IncRNA MALAT1 in H9 cells). Once produced, these IncRNAs are all localized to their site of production and form microscopically visible IncRNP accumulations, referred to here as PWS bodies (Fig. 2B; Wu et al. 2016). Super-resolution microscopy together with iCLIP RNA-seq revealed that these IncRNAs are colocalized with splicing factors RBFOX2, hnRNP $M$, and TDP43 and provide specific binding motifs with certain preferences (Wu et al. 2016). For example, snoIncRNAs prefer to bind RBFOX2 (UGCAU and GCAUG motifs), whereas SPA1 prefers to bind TDP43 (tandem UG-repeat sequences) as revealed by iCLIP analysis ( $\mathrm{Wu}$ et al. 2016). Quantitative imaging of each RBP and these PWS-region IncRNAs has shown that greater than $1 \%$ of each RBP could be sequestered by these IncRNAs, suggesting that the PWS body takes up $0.02 \%-0.1 \%$ of the nuclear volume but sequesters greater than $1 \%$ of each associated RBP. As a consequence, in a PWS hESC cellular model lacking all these seven IncRNAs, altered splicing events that are associated with the mislocalization of these RBPs on pre-mRNAs were identified (Wu et al. 2016). Some of the misregulated pre-mRNA splicing events were confirmed in hiPSCs derived from a PWS patient (Wu et al. 2016).

Another example can be illustrated by circRNAs, which are known to be expressed at a low level in general (Chen 2020). Using an optimized circSHAPE-MaP approach to measure the folding conformation of circRNAs (Liu et al. 2019), it was found that 26 out of 34 examined circRNAs contain one to four intramolecular 16- to 26-bp RNA duplexes (intra-dsRNAs), which are seen less frequently in their linear mRNA cognates. This has allowed the short intra-dsRNA-containing circRNAs to work as a group to bind PKR and prevent it from dimerization for activation (Fig. 2B; Liu et al. 2019). PKR is a double-stranded RNA-dependent protein kinase associated with direct antiviral activity and immune responses, and in this process, PKR activation requires dsRNAs longer than $33 \mathrm{bp}$, while short dsRNAs of 16 to 33 bp in length can block its activation (Zheng and Bevilacqua 2004; Bou-Nader et al. 2019). Given this structure-dependent, but sequence-independent, manner for PKR activation, and that each cell has $\sim 10,000$ copies of circRNAs many of which have one to four intra-dsRNA regions, circRNAs as a group can modulate PKR activation (Liu et al. 2019).

\section{InCRNA-INDUCED PROTEIN PHASE SEPARATION PROMOTES EFFICIENT InCRNP ASSEMBLY TO OUTCOMPETE THE SAME BINDING MOTIFS ON OTHER EXPRESSED RNAs}

Even for IncRNAs that are abundantly expressed at hundreds of copies per cell, they may still display a low stoichiometric ratio compared to total cellular expressed RNAs containing the same binding motifs for a particular protein. For example, NORAD plays a prominent role in genome stability by sequestering and antagonizing PUM1 and PUM2, which have inhibitory effects on mitotic, DNA repair, and DNA replication factors related to aberrant mitosis (Lee et al. 2016; Tichon et al. 2016). Depletion of Norad in mice causes premature aging due to augmented activity of PUM proteins (Kopp et al. 2019). NORAD is expressed at 400 copies per HCT116 cell, and each transcript contains 18 PREs (PUMILIO response elements) for PUM binding (Lee et al. 2016). Given that there are 15,000 PUM1 plus 2000 PUM2 proteins per cell, NORAD provides sufficient PUM1 and PUM2 binding sites to restrain functional PUM proteins (Lee et al. 2016). However, in terms of element number, these 7200 PREs $(400 \times 18)$ are unlikely to compete well against overall 130,000-325,000 PREs within the whole mRNA transcriptome (Fig. 3A; Elguindy and Mendell 2021).

PUM proteins contain large amino-terminally located IDRs. Super-resolution microscopy has shown that NORAD and PUM are colocalized in the cytosol to form microscopically visible foci named NP (NORAD and PUM) bodies. NP bodies have a liquid-liquid phase separation property, in which PUM protein phase separation is driven by NORAD in a PRE-number-dependent manner. NORAD thus efficiently sequesters PUM beyond simple competitive titration based on RNA valency and PRE abundance by creating a micro-environment to effectively recruit a large number of PUM to these sites. In such a model, once NORAD-PUM clustering via multivalent RNA-binding interactions is established, additional PUM will be recruited and concentrated by IDR-IDR interactions of PUM proteins and finally enlarged into a NP body.

Given the fact that many RBPs, for example, those enriched in paraspeckles, undergo phase separation (Hennig et al. 2015; Fox et al. 2018) and that the IncRNA NEAT1_2 mid-region itself contains a phase separation property (Yamazaki et al. 2018), it remains possible that paraspeckles, and likely other IncRNP complexes such as Xist RNP (Markaki et al. 2020), may nucleate their formation via an efficient multivalent mechanism, in addition to coupling with Pol II transcription (Mao et al. 2011a; Hnisz et al. 2017; Shrinivas et al. 2019; Rippe and Papantonis 2021). 
A

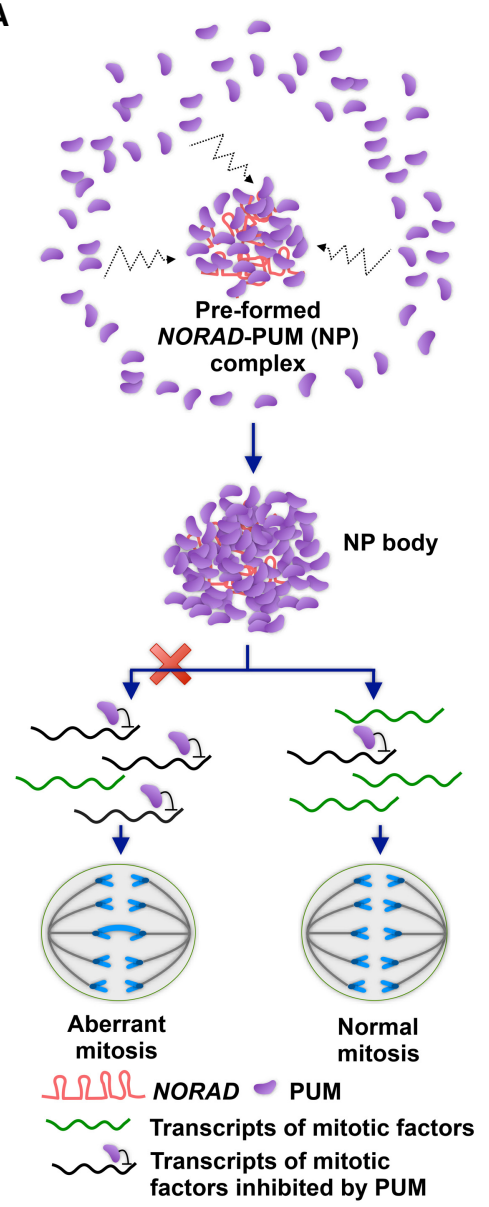

B

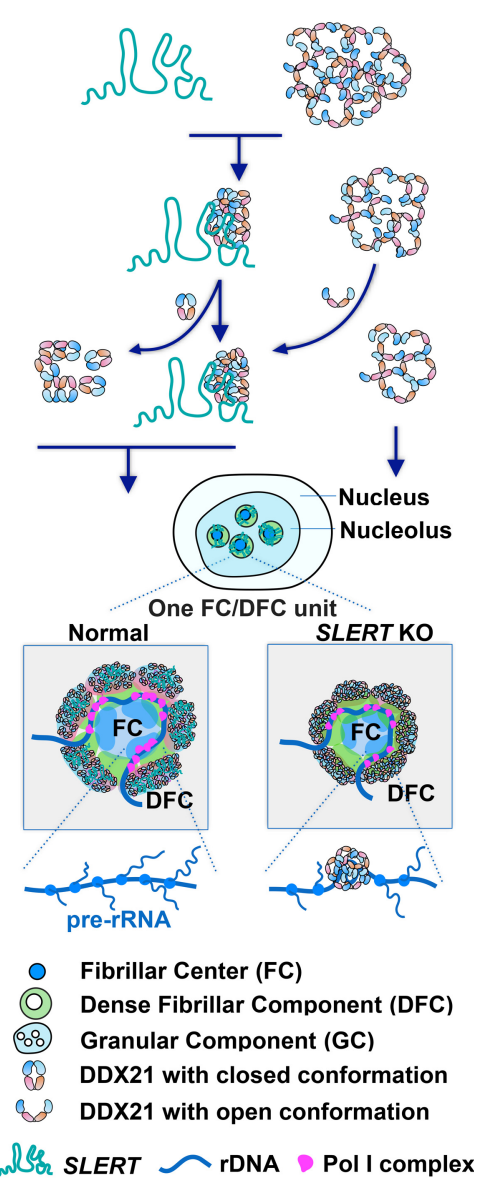

FIGURE 3. Mechanisms of super-stoichiometry of IncRNA-RBP interaction. (A) NORAD (noncoding RNA activated by DNA damage) drives PUMILLO (PUM) phase separation by multivalent NORAD-PUM and IDR-mediated PUM-PUM interactions to sequester outnumbered PUM proteins (Elguindy and Mendell 2021). NORAD outcompetes other cellular mRNAs by means of PRE (PUMILLO response element) valency and abundance, preventing aberrant mitosis by restraining PUM proteins within a narrow range (Lee et al. 2016; Tichon et al. 2016). (B) SLERT (snoRNA-ended IncRNA enhances preribosomal RNA transcription) is exclusively localized to the nucleolus (Xing et al. 2017). It interacts with the DEAD-box RNA helicase DDX21 with one loop region and transforms a large amount of DDX21 proteins from open to closed conformation by a molecular chaperone-like mechanism (Wu et al. 2021). Closed DDX21 molecules form loosened clusters surrounding FC/DFC to maintain the proper liquidity required for RNA polymerase I (Pol I) transcription (Wu et al. 2021).

\section{IncRNAs CAN PROMOTE CONFORMATIONAL CHANGE OF PROTEIN CLUSTERS BY A MOLECULAR CHAPERONE-LIKE MECHANISM AT A SUBSTOICHIOMETRIC RATIO}

Super resolution microscopy IncRNP in situ studies have shown an extremely low stoichiometric ratio of the IncRNA SLERT to its binding protein DDX21, which together play important roles in human nucleolar organization and Pol I transcription (Fig. 3B; Xing et al. 2017; Wu et al. 2021). In the nucleolus, Pol I transcription of rDNA occurs at the border of fibrillar centers (FC) and dense fibrillar components (DFC) (Fig. 3B), making FC/DFC organization as a unit for Pol I transcription and nascent pre-rRNA processing (Yao et al. 2019). SLERT is a H/ACA-type snoRNA-ended IncRNA, transcribed and processed from the TBRG4 locus, and then translocated to the nucleolus for function (Xing et al. 2017). Depletion of SLERT led to reduced cell proliferation, consistent with its role in promoting Pol I transcription (Xing et al. 2017).

SLERT is exclusively localized at FC/ DFC units, where it binds to DDX21 (Xing et al. 2017), a DEAD-box RNA helicase that can adopt an open or closed conformation upon substrate binding (Chen et al. 2020). DDX21 is largely enriched outside of each FC/ DFC, where it forms a discontinuous shell-like structure coating each $\mathrm{FC} /$ DFC by switching its intermolecular and intramolecular interactions mediated by unstructured amino- and carboxy-termini. Increased intermolecular interaction led to DDX21 multimerization, resulting in decreased size of the shell and FC/DFC structure, reduced mobility of FC/DFC components, and suppressed Pol I transcription (Fig. 3B; Wu et al. 2021). Intriguingly, there are about 13 SLERT and 13,000 DDX21 molecules per FC/DFC (Wu et al. 2021), and yet these 13 SLERT are capable of promoting the significantly more abundant DDX21 proteins in FC/DFC to adopt a closed conformation, ultimately leading to the loosened environment of an FC/DFC unit and proper Pol I transcription (Fig. 3B; Wu et al. 2021). SLERT prefers to bind DDX21 with open conformation. It was proposed that under this super-stoichiometric ratio, once SLERT induces a DDX21 protein to adopt the closed conformation, this DDX21 would be released, allowing the recruitment of another one with an open conformation to initiate conformational transition, resulting in the formation of hypomultimerized DDX21 molecules in FC/DFC, which is required for FC/DFC liquidity and Pol I processivity. Moreover, without SLERT, DDX21 clusters are strongly engaged with rDNAs to prevent Pol I binding to rDNAs for transcription (Fig. 3B).

How exactly SLERT acts as a molecular chaperone to coordinate DDX21 conformational change in clusters warrants future studies that will require the development of 
new methods for the analysis of phase-separated IncRNPs. Nevertheless, both studies (Fig. 3A,B) have raised the intriguing possibility that IncRNPs may work as clusters in certain condensates, rather than independently in solution as previously thought.

\section{PERSPECTIVES}

Functional studies on IncRNAs have been burgeoning in the past decade. Numerous efforts have been made to explore their biogenesis, expression, localization, turnover, conformation, and function. These efforts have led to our current understanding of how IncRNAs use different mechanisms to overcome their naturally low expression to effectively interact with protein partners. More efforts are certainly needed to understand particular IncRNP complexes by developing new approaches to decode their molecular basis for interactions and to visualize their dynamics at the single molecule and suborganelle levels.

\section{ACKNOWLEDGMENTS}

We apologize to colleagues whose work could not be discussed owing to space limitations. This work was supported by the National Natural Science Foundation of China (NSFC) (31725009, 31830108), the Chinese Academy of Sciences (CAS) (YSBR-009), the Shanghai Municipal Commission for Science and Technology (20JC1410300), and the Howard Hughes Medical Institute (HHMI) International Program (55008728) to L.-L.C. L.-L.C. acknowledges support from the Xplorer Prize.

\section{REFERENCES}

Aebersold R, Mann M. 2003. Mass spectrometry-based proteomics. Nature 422: 198-207. doi:10.1038/nature01511

Ahrne E, Molzahn L, Glatter T, Schmidt A. 2013. Critical assessment of proteome-wide label-free absolute abundance estimation strategies. Proteomics 13: 2567-2578. doi:10.1002/pmic.201300135

Andersen JS, Lam YW, Leung AKL, Ong SE, Lyon CE, Lamond AI, Mann M. 2005. Nucleolar proteome dynamics. Nature 433: 7783. doi:10.1038/nature03207

Arab K, Park YJ, Lindroth AM, Schafer A, Oakes C, Weichenhan D, Lukanova A, Lundin E, Risch A, Meister M, et al. 2014. Long noncoding RNA TARID directs demethylation and activation of the tumor suppressor TCF21 via GADD45A. Mol Cell 55: 604-614. doi:10.1016/j.molcel.2014.06.031

Arab K, Karaulanov E, Musheev M, Trnka P, Schafer A, Grummt I, Niehrs C. 2019. GADD45A binds R-loops and recruits TET1 to CpG island promoters. Nat Genet 51: 217. doi:10.1038/s41588018-0306-6

Atianand MK, Hu W, Satpathy AT, Shen Y, Ricci EP, AlvarezDominguez JR, Bhatta A, Schattgen SA, McGowan JD, Blin J, et al. 2016. A long noncoding RNA lincRNA-EPS acts as a transcriptional brake to restrain inflammation. Cell 165: 1672-1685. doi:10.1016/j.cell.2016.05.075

Bao X, Wu H, Zhu X, Guo X, Hutchins AP, Luo Z, Song H, Chen Y, Lai K, Yin $M$, et al. 2015. The p53-induced lincRNA-p21 derails somatic cell reprogramming by sustaining $\mathrm{H} 3 \mathrm{~K} 9 \mathrm{me} 3$ and $\mathrm{CpG}$ methylation at pluripotency gene promoters. Cell Res 25: 80-92. doi:10.1038/ cr.2014.165

Bartkiewicz M, Gold H, Altman S. 1989. Identification and characterization of an RNA molecule that copurifies with RNase P activity from HeLa cells. Genes Dev 3: 488-499. doi:10.1101/gad.3.4.488

Bosch JA, Chen CL, Perrimon N. 2021. Proximity-dependent labeling methods for proteomic profiling in living cells: an update. Wires Dev Biol 10: e392. doi:10.1002/wdev.392

Bou-Nader C, Gordon JM, Henderson FE, Zhang JW. 2019. The search for a PKR code-differential regulation of protein kinase $\mathrm{R}$ activity by diverse RNA and protein regulators. RNA 25: 539-556. doi:10.1261/rna.070169.118

Brockdorff N. 2018. Local tandem repeat expansion in Xist RNA as a model for the functionalisation of ncRNA. Noncoding RNA 4: 28. doi:10.3390/ncrna4040028

Brown CJ, Hendrich BD, Rupert JL, Lafreniere RG, Xing Y, Lawrence J, Willard HF. 1992. The human Xist gene: analysis of a $17 \mathrm{~Kb}$ inactive $X$-specific RNA that contains conserved repeats and is highly localized within the nucleus. Cell 71: 527-542. doi:10.1016/0092-8674 (92)90520-M

Budnik B, Levy E, Harmange G, Slavov N. 2018. SCoPE-MS: mass spectrometry of single mammalian cells quantifies proteome heterogeneity during cell differentiation. Genome Biol 19: 161. doi:10.1186/s13059-018-1547-5

Cabili MN, Dunagin MC, McClanahan PD, Biaesch A, PadovanMerhar O, Regev A, Rinn JL, Raj A. 2015. Localization and abundance analysis of human IncRNAs at single-cell and single-molecule resolution. Genome Biol 16: 20. doi:10.1186/s13059-0150586-4

Castello A, Fischer B, Eichelbaum K, Horos R, Beckmann BM, Strein C, Davey NE, Humphreys DT, Preiss T, Steinmetz LM, et al. 2012. Insights into RNA biology from an atlas of mammalian mRNAbinding proteins. Cell 149: 1393-1406. doi:10.1016/j.cell.2012 .04 .031

Castello A, Fischer B, Frese CK, Horos R, Alleaume AM, Foehr S, Curk T, Krijgsveld J, Hentze MW. 2016. Comprehensive identification of RNA-binding domains in human cells. Mol Cell 63: 696710. doi:10.1016/j.molcel.2016.06.029

Caudron-Herger M, Pankert T, Seiler J, Nemeth A, Voit R, Grummt I, Rippe K. 2015. Alu element-containing RNAs maintain nucleolar structure and function. EMBO J 34: 2758-2774. doi:10.15252/ embj.201591458

Chelius D, Bondarenko PV. 2002. Quantitative profiling of proteins in complex mixtures using liquid chromatography and mass spectrometry. J Proteome Res 1: 317-323. doi:10.1021/pr025517j

Chen LL. 2020. The expanding regulatory mechanisms and cellular functions of circular RNAs. Nat Rev Mol Cell Biol 21: 475-490. doi:10.1038/s41580-020-0243-y

Chen LL, DeCerbo JN, Carmichael GG. 2008. Alu element-mediated gene silencing. EMBO J 27: 1694-1705. doi:10.1038/emboj .2008 .94

Chen ZJ, Li ZY, Hu XJ, Xie FY, Kuang SY, Zhan BW, Gao WQ, Chen XJ, Gao SQ, Li Y, et al. 2020. Structural basis of human helicase DDX21 in RNA binding, unwinding, and antiviral signal activation. Adv Sci 7: 2000532. doi:10.1002/advs.202000532

Cheng YT, Jutooru I, Chadalapaka G, Corton JC, Safe S. 2015. The long non-coding RNA HOTTIP enhances pancreatic cancer cell proliferation, survival and migration. Oncotarget 6: 1084010852. doi:10.18632/oncotarget. 3450

Choi-Rhee E, Schulman H, Cronan JE. 2004. Promiscuous protein biotinylation by Escherichia coli biotin protein ligase. Protein Sci 13: 3043-3050. doi:10.1110/ps.04911804

Chu C, Zhang OFC, da Rocha ST, Flynn RA, Bharadwaj M, Calabrese JM, Magnuson T, Heard E, Chang HY. 2015. 
Systematic discovery of Xist RNA binding proteins. Cell 161: 404 416. doi:10.1016/j.cell.2015.03.025

Chujo T, Yamazaki T, Kawaguchi T, Kurosaka S, Takumi T, Nakagawa S, Hirose T. 2017. Unusual semi-extractability as a hallmark of nuclear body-associated architectural noncoding RNAs. EMBO J 36: 1447-1462. doi:10.15252/embj.201695848

Cohen SB, Graham ME, Lovrecz GO, Bache N, Robinson PJ, Reddel RR. 2007. Protein composition of catalytically active human telomerase from immortal cells. Science 315: 1850-1853. doi:10 $.1126 /$ science. 1138596

Colognori D, Sunwoo H, Kriz AJ, Wang CY, Lee JT. 2019. Xist deletional analysis reveals an interdependency between Xist RNA and polycomb complexes for spreading along the inactive X. Mol Cell 74: 101. doi:10.1016/j.molcel.2019.01.015

Das S, Pal U, Das S, Bagga K, Roy A, Mrigwani A, Maiti NC. 2014. Sequence complexity of amyloidogenic regions in intrinsically disordered human proteins. PLoS ONE 9: e89781. doi:10.1371/jour nal.pone.0089781

DeCaprio J, Kohl TO. 2020. Differential detergent lysis of cellular fractions for immunoprecipitation. Cold Spring Harb Protoc 2020: 098582. doi:10.1101/pdb.prot098582

Derrien T, Johnson R, Bussotti G, Tanzer A, Djebali S, Tilgner $H$, Guernec G, Martin D, Merkel A, Knowles DG, et al. 2012. The GENCODE v7 catalog of human long noncoding RNAs: analysis of their gene structure, evolution, and expression. Genome Res 22: 1775-1789. doi:10.1101/gr.132159.111

Dossin F, Pinheiro I, Zylicz JJ, Roensch J, Collombet S, Le Saux A, Chelmicki T, Attia M, Kapoor V, Zhan Y, et al. 2020. SPEN integrates transcriptional and epigenetic control of $\mathrm{X}$-inactivation. Nature 578: 455. doi:10.1038/s41586-020-1974-9

Elguindy MM, Mendell JT. 2021. NORAD-induced Pumilio phase separation is required for genome stability. Nature 595: 303-308. doi:10.1038/s41586-021-03633-w

Essers PB, Nonnekens J, Goos YJ, Betist MC, Viester MD, Mossink B, Lansu N, Korswagen HC, Jelier R, Brenkman AB, et al. 2015. A long noncoding RNA on the ribosome is required for lifespan extension. Cell Rep 10: 339-345. doi:10.1016/j.celrep.2014.12.029

Evans D, Marquez SM, Pace NR. 2006. RNase P: interface of the RNA and protein worlds. Trends Biochem Sci 31: 333-341. doi:10 .1016/j.tibs.2006.04.007

Feretzaki M, Pospisilova M, Valador Fernandes R, Lunardi T, Krejci L, Lingner J. 2020. RAD51-dependent recruitment of TERRA IncRNA to telomeres through R-loops. Nature 587: 303-308. doi:10.1038/s41586-020-2815-6

Fox AH, Lam YW, Leung AKL, Lyon CE, Andersen J, Mann M, Lamond Al. 2002. Paraspeckles: a novel nuclear domain. Curr Biol 12: 13-25. doi:10.1016/S0960-9822(01)00632-7

Fox AH, Bond CS, Lamond Al. 2005. P54nrb forms a heterodimer with PSP1 that localizes to paraspeckles in an RNA-dependent manner. Mol Biol Cell 16: 5304-5315. doi:10.1091/mbc.e05-06-0587

Fox AH, Nakagawa S, Hirose T, Bond CS. 2018. Paraspeckles: where long noncoding RNA meets phase separation. Trends Biochem Sci 43: 124-135. doi:10.1016/j.tibs.2017.12.001

Ghanim GE, Fountain AJ, van Roon AM, Rangan R, Das R, Collins K, Nguyen THD. 2021. Structure of human telomerase holoenzyme with bound telomeric DNA. Nature 593: 449-453. doi:10.1038/ s41586-021-03415-4

Gray MW, Gopalan V. 2020. Piece by piece: building a ribozyme. J Biol Chem 295: 2313-2323. doi:10.1074/jbc.REV119.009929

Guerrier-Takada C, Gardiner K, Marsh T, Pace N, Altman S. 1983. The RNA moiety of ribonuclease $P$ is the catalytic subunit of the enzyme. Cell 35: 849-857. doi:10.1016/0092-8674(83)90117-4

Guillen-Boixet J, Kopach A, Holehouse AS, Wittmann S, Jahnel M, Schlussler R, Kim K, Trussina IREA, Wang J, Mateju D, et al. 2020. RNA-induced conformational switching and clustering of
G3BP drive stress granule assembly by condensation. Cell 181: 346. doi:10.1016/j.cell.2020.03.049

Guo CJ, Ma XK, Xing YH, Zheng CC, Xu YF, Shan L, Zhang J, Wang S, Wang Y, Carmichael GG, et al. 2020. Distinct processing of IncRNAs contributes to non-conserved functions in stem cells. Cell 181: 621-636.e22. doi:10.1016/j.cell.2020.03.006

Gygi SP, Rist B, Gerber SA, Turecek F, Gelb MH, Aebersold R. 1999. Quantitative analysis of complex protein mixtures using isotopecoded affinity tags. Nat Biotechnol 17: 994-999. doi:10.1038/ 13690

Hansji H, Leung EY, Baguley BC, Finlay GJ, Cameron-Smith D, Figueiredo VC, Askarian-Amiri ME. 2016. ZFAS1: a long noncoding RNA associated with ribosomes in breast cancer cells. Biol Direct 11: 62. doi:10.1186/s13062-016-0165-y

Hartshorn C, Rice JE, Wangh LJ. 2003. Differential pattern of Xist RNA accumulation in single blastomeres isolated from 8-cell stage mouse embryos following laser zona drilling. Mol Reprod Dev 64: 41-51. doi:10.1002/mrd.10223

Hein MY, Hubner NC, Poser I, Cox J, Nagaraj N, Toyoda Y, Gak IA, Weisswange I, Mansfeld J, Buchholz F, et al. 2015. A human interactome in three quantitative dimensions organized by stoichiometries and abundances. Cell 163: 712-723. doi:10.1016/j.cell .2015.09.053

Hennig S, Kong G, Mannen T, Sadowska A, Kobelke S, Blythe A, Knott GJ, lyer KS, Ho D, Newcombe EA, et al. 2015. Prion-like domains in RNA binding proteins are essential for building subnuclear paraspeckles. J Cell Biol 210: 529-539. doi:10.1083/jcb .201504117

Hnisz D, Shrinivas K, Young RA, Chakraborty AK, Sharp PA. 2017. A phase separation model for transcriptional control. Cell 169: 1323. doi:10.1016/j.cell.2017.02.007

Hopkins C, Gibson A, Stinchcombe J, Futter C. 2000. Chimeric molecules employing horseradish peroxidase as reporter enzyme for protein localization in the electron microscope. Methods Enzymol 327: 35-45. doi:10.1016/S0076-6879(00)27265-0

Hung V, Udeshi ND, Lam SS, Loh KH, Cox KJ, Pedram K, Carr SA, Ting AY. 2016. Spatially resolved proteomic mapping in living cells with the engineered peroxidase APEX2. Nat Protoc 11: 456-475. doi:10.1038/nprot.2016.018

Kim NW, Piatyszek MA, Prowse KR, Harley CB, West MD, Ho PL, Coviello GM, Wright WE, Weinrich SL, Shay JW. 1994. Specific association of human telomerase activity with immortal cells and cancer. Science 266: 2011-2015. doi:10.1126/science.7605428

Kim DH, Marinov GK, Pepke S, Singer ZS, He P, Williams B, Schroth GP, Elowitz MB, Wold BJ. 2015. Single-cell transcriptome analysis reveals dynamic changes in IncRNA expression during reprogramming. Cell Stem Cell 16: 88-101. doi:10.1016/j.stem .2014 .11 .005

Kopp F, Mendell JT. 2018. Functional classification and experimental dissection of long noncoding RNAs. Cell 172: 393-407. doi:10 .1016/j.cell.2018.01.011

Kopp F, Elguindy MM, Yalvac ME, Zhang H, Chen B, Gillett FA, Lee S, Sivakumar S, Yu H, Xie Y, et al. 2019. PUMILIO hyperactivity drives premature aging of Norad-deficient mice. Elife 8: e42650. doi:10 $.7554 /$ eLife. 42650

Lafontaine DLJ, Riback JA, Bascetin R, Brangwynne CP. 2021. The nucleolus as a multiphase liquid condensate. Nat Rev Mol Cell Bio 22: 165-182. doi:10.1038/s41580-020-0272-6

Lan PF, Zhou B, Tan M, Li SB, Cao M, Wu J, Lei M. 2020. Structural insight into precursor ribosomal RNA processing by ribonuclease MRP. Science 369: 656. doi:10.1126/science.abc0149

Lee JT, Bartolomei MS. 2013. X-inactivation, imprinting, and long noncoding RNAs in health and disease. Cell 152: 1308-1323. doi:10.1016/j.cell.2013.02.016 
Lee S, Kopp F, Chang TC, Sataluri A, Chen B, Sivakumar S, Yu H, Xie Y, Mendell JT. 2016. Noncoding RNA NORAD regulates genomic stability by sequestering PUMILIO proteins. Cell 164: 69-80. doi:10.1016/j.cell.2015.12.017

Leucci E, Vendramin R, Spinazzi M, Laurette P, Fiers M, Wouters J, Radaelli E, Eyckerman S, Leonelli C, Vanderheyden K, et al. 2016. Melanoma addiction to the long non-coding RNA SAMMSON. Nature 531: 518-522. doi:10.1038/nature17161

Li XW, Rees JS, Xue P, Zhang H, Hamaia SW, Sanderson B, Funk PE, Farndale RW, Lilley KS, Perrett S, et al. 2014. New insights into the DT40 B cell receptor cluster using a proteomic proximity labeling assay. J Biol Chem 289: 14434-14447. doi:10.1074/jbc.M113 .529578

Li Y, Syed J, Sugiyama H. 2016. RNA-DNA triplex formation by long noncoding RNAs. Cell Chem Biol 23: 1325-1333. doi:10.1016/j .chembiol.2016.09.011

Li S, Li X, Xue W, Zhang L, Yang LZ, Cao SM, Lei YN, Liu CX, Guo SK, Shan $L$, et al. 2021. Screening for functional circular RNAs using the CRISPR-Cas13 system. Nat Methods 18: 51-59. doi:10.1038/ s41592-020-01011-4

Liu Q, Zheng J, Sun WP, Huo YB, Zhang LY, Hao PL, Wang HP, Zhuang M. 2018. A proximity-tagging system to identify membrane protein-protein interactions. Nat Methods 15: 715. doi:10 .1038/s41592-018-0100-5

Liu CX, Li X, Nan F, Jiang S, Gao X, Guo SK, Xue W, Cui Y, Dong K, Ding $H$, et al. 2019. Structure and degradation of circular RNAs regulate PKR activation in innate immunity. Cell 177: 865-880. e21. doi:10.1016/j.cell.2019.03.046

Lo Piccolo L, Bonaccorso R, Onorati MC. 2015. Nuclear and cytoplasmic soluble proteins extraction from a small quantity of Drosophila's whole larvae and tissues. Int J Mol Sci 16: 1236012367. doi:10.3390/ijms160612360

Ludwig C, Claassen M, Schmidt A, Aebersold R. 2012. Estimation of absolute protein quantities of unlabeled samples by selected reaction monitoring mass spectrometry. Mol Cell Proteomics 11: M111.013987. doi:10.1074/mcp.M111.013987

Luo HC, Zhu GQ, Xu JF, Lai Q, Yan BW, Guo Y, Fung TK, Zeisig BB, Cui Y, Zha J, et al. 2019. HOTTIP IncRNA promotes hematopoietic stem cell self-renewal leading to AML-like disease in mice. Cancer Cell 36: 645. doi:10.1016/j.ccell.2019.10.011

Maharana S, Wang J, Papadopoulos DK, Richter D, Pozniakovsky A, Poser I, Bickle M, Rizk S, Guillen-Boixet J, Franzmann TM, et al. 2018. RNA buffers the phase separation behavior of prion-like RNA binding proteins. Science 360: 918-921. doi:10.1126/sci ence.aar7366

Mao YTS, Sunwoo H, Zhang B, Spector DL. 2011a. Direct visualization of the co-transcriptional assembly of a nuclear body by noncoding RNAs. Nat Cell Biol 13: 95-101. doi:10.1038/ncb2140

Mao YTS, Zhang B, Spector DL. 2011b. Biogenesis and function of nuclear bodies. Trends Genet 27: 295-306. doi:10.1016/j.tig.2011 .05 .006

Markaki Y, Chong JG, Luong C, Tan SYX, Wang Y, Jacobson EC, Maestrini D, Dror I, Mistry BA, Schöneberg J, et al. 2020. Xistseeded nucleation sites form local concentration gradients of silencing proteins to inactivate the $\mathrm{X}$-chromosome. bioRxiv doi:10 $.1101 / 2020.11 .22 .393546$

Martell JD, Deerinck TJ, Sancak Y, Poulos TL, Mootha VK, Sosinsky GE, Ellisman MH, Ting AY. 2012. Engineered ascorbate peroxidase as a genetically encoded reporter for electron microscopy. Nat Biotechnol 30: 1143-1148. doi:10.1038/nbt.2375

McHugh CA, Chen CK, Chow A, Surka CF, Tran C, McDonel P, Pandya-Jones A, Blanco M, Burghard C, Moradian A, et al. 2015. The Xist IncRNA interacts directly with SHARP to silence transcription through HDAC3. Nature 521: 232-236. doi:10 $.1038 /$ nature14443
Mumbach MR, Granja JM, Flynn RA, Roake CM, Satpathy AT, Rubin AJ, Qi Y, Jiang Z, Shams S, Louie BH, et al. 2019. HiChIRP reveals RNA-associated chromosome conformation. Nat Methods 16: 489-492. doi:10.1038/s41592-019-0407-x

Ong SE, Blagoev B, Kratchmarova I, Kristensen DB, Steen H, Pandey A, Mann M. 2002. Stable isotope labeling by amino acids in cell culture, SILAC, as a simple and accurate approach to expression proteomics. Mol Cell Proteomics 1: 376-386. doi:10.1074/ mcp.M200025-MCP200

Postepska-Igielska A, Giwojna A, Gasri-Plotnitsky L, Schmitt N, Dold A, Ginsberg D, Grummt I. 2015. LncRNA Khps1 regulates expression of the proto-oncogene SPHK1 via triplex-mediated changes in chromatin structure. Mol Cell 60: 626-636. doi:10 .1016/j.molcel.2015.10.001

Ramsby M, Makowski G. 2011. Differential detergent fractionation of eukaryotic cells. Cold Spring Harb Protoc 2011: prot5592. doi:10 $.1101 /$ pdb.prot5592

Rippe K, Papantonis A. 2021. RNA polymerase II transcription compartments: from multivalent chromatin binding to liquid droplet formation? Nat Rev Mol Cell Biol 22: 645-646. doi:10.1038/ s41580-021-00401-6

Ross PL, Huang YLN, Marchese JN, Williamson B, Parker K, Hattan S, Khainovski N, Pillai S, Dey S, Daniels S, et al. 2004. Multiplexed protein quantitation in Saccharomyces cerevisiae using amine-reactive isobaric tagging reagents. Mol Cell Proteomics 3: 11541169. doi:10.1074/mcp.M400129-MCP200

Roux KJ, Kim DI, Raida M, Burke B. 2012. A promiscuous biotin ligase fusion protein identifies proximal and interacting proteins in mammalian cells. J Cell Biol 196: 801-810. doi:10.1083/jcb.201112098

Sasaki YTF, Hirose T. 2009. How to build a paraspeckle. Genome Biol 10: 227. doi:10.1186/gb-2009-10-7-227

Sasaki YT, Ideue T, Sano M, Mituyama T, Hirose T. 2009. MEN $\varepsilon / \beta$ noncoding RNAs are essential for structural integrity of nuclear paraspeckles. Proc Natl Acad Sci 106: 2525-2530. doi:10.1073/pnas 0807899106

Schmidt JC, Cech TR. 2015. Human telomerase: biogenesis, trafficking, recruitment, and activation. Genes Dev 29: 1095-1105. doi:10.1101/gad.263863.115

Schubert OT, Rost HL, Collins BC, Rosenberger G, Aebersold R. 2017. Quantitative proteomics: challenges and opportunities in basic and applied research. Nat Protoc 12: 1289-1294. doi:10.1038/ nprot.2017.040

Seifuddin F, Singh K, Suresh A, Judy JT, Chen YC, Chaitankar V, Tunc I, Ruan XB, Li P, Chen Y, et al. 2020. IncRNAKB, a knowledgebase of tissue-specific functional annotation and trait association of long noncoding RNA. Sci Data 7: 326. doi:10.1038/s41597020-00659-z

Shrinivas K, Sabari BR, Coffey EL, Klein IA, Boija A, Zamudio AV, Schuijers J, Hannett NM, Sharp PA, Young RA, et al. 2019. Enhancer features that drive formation of transcriptional condensates. Mol Cell 75: 549. doi:10.1016/j.molcel.2019.07.009

Simko EAJ, Liu HH, Zhang T, Velasquez A, Teli S, Haeusler AR, Wang JO. 2020. G-quadruplexes offer a conserved structural motif for NONO recruitment to NEAT1 architectural IncRNA. Nucleic Acids Res 48: 7421-7438. doi:10.1093/nar/gkaa475

Statello L, Guo CJ, Chen LL, Huarte M. 2021. Gene regulation by long non-coding RNAs and its biological functions. Nat Rev Mol Cell Biol 22: 96-118. doi:10.1038/s41580-020-00315-9

St Laurent G, Wahlestedt C, Kapranov P. 2015. The landscape of long noncoding RNA classification. Trends Genet 31: 239-251. doi:10 .1016/j.tig.2015.03.007

Sun Q, Hao Q, Prasanth KV. 2018. Nuclear long noncoding RNAs: key regulators of gene expression. Trends Genet 34: 142-157. doi:10 .1016/j.tig.2017.11.005 
Sunwoo H, Wu JY, Lee JT. 2015. The Xist RNA-PRC2 complex at 20$\mathrm{nm}$ resolution reveals a low Xist stoichiometry and suggests a hitand-run mechanism in mouse cells. Proc Natl Acad Sci 112: E4216-E4225. doi:10.1073/pnas. 1503690112

Takata H, Nishijima H, Ogura S, Sakaguchi T, Bubulya PA, Mochizuki T, Shibahara K. 2009. Proteome analysis of human nuclear insoluble fractions. Genes Cells 14: 975-990. doi:10.1111/j .1365-2443.2009.01324.x

Tichon A, Gil N, Lubelsky Y, Havkin Solomon T, Lemze D, Itzkovitz S, Stern-Ginossar N, Ulitsky I. 2016. A conserved abundant cytoplasmic long noncoding RNA modulates repression by Pumilio proteins in human cells. Nat Commun 7: 12209. doi:10.1038/ ncomms 12209

Tukiainen T, Villani AC, Yen A, Rivas MA, Marshall JL, Satija R, Aguirre M, Gauthier L, Fleharty M, Kirby A, et al. 2017. Landscape of $\mathrm{X}$ chromosome inactivation across human tissues. Nature 550: 244. doi:10.1038/nature24265

Wang KC, Yang YW, Liu B, Sanyal A, Corces-Zimmerman R, Chen Y, Lajoie BR, Protacio A, Flynn RA, Gupta RA, et al. 2011. A long noncoding RNA maintains active chromatin to coordinate homeotic gene expression. Nature 472: 120-124. doi:10.1038/nature09819

Wang P, Xu JF, Wang YJ, Cao XT. 2017. An interferon-independent IncRNA promotes viral replication by modulating cellular metabolism. Science 358: 1051-1055. doi:10.1126/science.aao0409

Wang XX, He Y, Ye Y, Zhao XY, Deng S, He G, Zhu HX, Xu NZ, Liang SF. 2018a. SILAC-based quantitative MS approach for realtime recording protein-mediated cell-cell interactions. Sci Rep 8: 8441. doi:10.1038/s41598-018-26262-2

Wang Y, Hu SB, Wang MR, Yao RW, Wu D, Yang L, Chen LL. $2018 \mathrm{~b}$. Genome-wide screening of NEAT1 regulators reveals cross-regulation between paraspeckles and mitochondria. Nat Cell Biol 20: 1145. doi:10.1038/s41556-018-0204-2

Wang X, Hu X, Song W, Xu H, Xiao Z, Huang R, Bai Q, Zhang F, Chen Y, Liu Y, et al. 2021. Mutual dependency between IncRNA LETN and protein NPM1 in controlling the nucleolar structure and functions sustaining cell proliferation. Cell Res 31: 664-683. doi:10.1038/s41422-020-00458-6

West JA, Davis CP, Sunwoo H, Simon MD, Sadreyev Rl, Wang PI, Tolstorukov MY, Kingston RE. 2014. The long noncoding RNAs NEAT1 and MALAT1 bind active chromatin sites. Mol Cell 55: 791-802. doi:10.1016/j.molcel.2014.07.012

West JA, Mito M, Kurosaka S, Takumi T, Tanegashima C, Chujo T, Yanaka K, Kingston RE, Hirose T, Bond C, et al. 2016. Structural, super-resolution microscopy analysis of paraspeckle nuclear body organization. J Cell Biol 214: 817-830. doi:10.1083/jcb .201601071

Wu H, Yin QF, Luo Z, Yao RW, Zheng CC, Zhang J, Xiang JF, Yang L, Chen LL. 2016. Unusual processing generates SPA IncRNAs that sequester multiple RNA binding proteins. Mol Cell 64: 534-548. doi:10.1016/j.molcel.2016.10.007

Wu H, Yang L, Chen LL. 2017. The diversity of long noncoding RNAs and their generation. Trends Genet 33: 540-552. doi:10.1016/j.tig .2017 .05 .004

Wu M, Xu G, Han C, Luan PF, Xing YH, Nan F, Yang LZ, Huang Y, Yang ZH, Shan L, et al. 2021. IncRNA SLERT controls phase sepa- ration of FC/DFCs to facilitate Pol I transcription. Science 373: 547-555. doi:10.1126/science.abf6582

Xi L, Cech TR. 2014. Inventory of telomerase components in human cells reveals multiple subpopulations of hTR and hTERT. Nucleic Acids Res 42: 8565-8577. doi:10.1093/nar/gku560

Xing YH, Yao RW, Zhang Y, Guo CJ, Jiang S, Xu G, Dong R, Yang L, Chen LL. 2017. SLERT regulates DDX21 rings associated with Pol I transcription. Cell 169: 664-678 e616. doi:10.1016/j.cell 2017.04.011

Yamazaki T, Souquere S, Chujo T, Kobelke S, Chong YS, Fox AH, Bond CS, Nakagawa S, Pierron G, Hirose T. 2018. Functional domains of NEAT1 architectural IncRNA induce paraspeckle assembly through phase separation. Mol Cell 70: 1038-1053.e7. doi:10.1016/j.molcel.2018.05.019

Yang F, Zhang H, Mei Y, Wu M. 2014. Reciprocal regulation of HIF-1 $\alpha$ and lincRNA-p21 modulates the Warburg effect. Mol Cell 53: 88100. doi:10.1016/j.molcel.2013.11.004

Yao RW, Xu G, Wang Y, Shan L, Luan PF, Wang Y, Wu M, Yang LZ, Xing $Y H$, Yang L, et al. 2019. Nascent pre-rRNA sorting via phase separation drives the assembly of dense fibrillar components in the human nucleolus. Mol Cell 76: 767-783.e11. doi:10.1016/j.molcel .2019 .08 .014

Yap K, Mukhina S, Zhang G, Tan JSC, Ong HS, Makeyev EV. 2018. A short tandem repeat-enriched RNA assembles a nuclear compartment to control alternative splicing and promote cell survival. Mol Cell 72: 525-540.e13. doi:10.1016/j.molcel.2018.08.041

Yin QF, Yang L, Zhang Y, Xiang JF, Wu YW, Carmichael GG, Chen LL. 2012. Long noncoding RNAs with snoRNA ends. Mol Cell 48: 219230. doi:10.1016/j.molcel.2012.07.033

Zhang XO, Yin QF, Wang HB, Zhang Y, Chen T, Zheng P, Lu XH, Chen LL, Yang L. 2014. Species-specific alternative splicing leads to unique expression of sno-IncRNAs. BMC Genomics 15: 287. doi:10.1186/1471-2164-15-287

Zhang HY, Elbaum-Garfinkle S, Langdon EM, Taylor N, Occhipinti P, Bridges AA, Brangwynne CP, Gladfelter AS. 2015. RNA controls polyO protein phase transitions. Mol Cell 60: 220-230. doi:10 .1016/j.molcel.2015.09.017

Zhao L, Wang J, Li Y, Song T, Wu Y, Fang S, Bu D, Li H, Sun L, Pei D, et al. 2021. NONCODEV6: an updated database dedicated to long non-coding RNA annotation in both animals and plants. Nucleic Acids Res 49: D165-D171. doi:10.1093/nar/ gkaa1046

Zheng XF, Bevilacqua PC. 2004. Activation of the protein kinase PKR by short double-stranded RNAs with single-stranded tails. RNA 10: 1934-1945. doi:10.1261/rna.7150804

Zhou HX, Nguemaha V, Mazarakos K, Qin SB. 2018. Why do disordered and structured proteins behave differently in phase separation? Trends Biochem Sci 43: 499-516. doi:10.1016/j.tibs .2018.03.007

Zhu Y, Piehowski PD, Zhao R, Chen J, Shen YF, Moore RJ, Shukla AK, Petyuk VA, Campbell-Thompson M, Mathews CE, et al. 2018. Nanodroplet processing platform for deep and quantitative proteome profiling of 10-100 mammalian cells. Nat Commun 9: 882. doi:10.1038/s41467-018-03367-w 

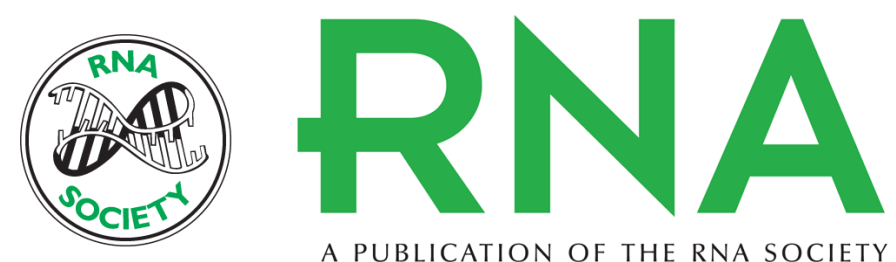

A PUBLICATION OF THE RNA SOCIETY

\section{Long noncoding RNA and protein abundance in IncRNPs}

Man Wu, Liang-Zhong Yang and Ling-Ling Chen

RNA 2021 27: 1427-1440 originally published online September 15, 2021

Access the most recent version at doi:10.1261/rna.078971.121

\section{References This article cites 118 articles, 26 of which can be accessed free at: http://rnajournal.cshlp.org/content/27/12/1427.full.html\#ref-list-1}

Open Access Freely available online through the RNA Open Access option.

Creative This article, published in RNA, is available under a Creative Commons License

Commons (Attribution-NonCommercial 4.0 International), as described at

License http://creativecommons.org/licenses/by-nc/4.0/.

Email Alerting Receive free email alerts when new articles cite this article - sign up in the box at the Service top right corner of the article or click here. 